\title{
HUBUNGAN ASUPAN PROTEIN DENGAN TEKANAN DARAH PADA REMAJA
}

\author{
Rika Purwani, Nurmasari Widyastuti*) \\ Program Studi Ilmu Gizi Fakultas Kedokteran Universitas Diponegoro \\ Jl.Dr.Sutomo No.18, Semarang, Telp (024) 8453708, Email : gizifk@undip.ac.id
}

\begin{abstract}
Background: Hypertension not only could affect adults but also adolescents. Adolescents with hypertension could continue in adulthood and had an higher increased risk of mortality. Many factors could affect blood pressure in adolescent, especially food intake. Recent research showed that there was a relationship between protein intake and blood pressure.

Objective: The aimed of this study was to determined the correlation of protein intake with blood pressure in adolescents.

Method: This cross sectional study was obtained on 64 subjects of SMP Kesatrian 2 Semarang, selected by simple random sampling. Protein intake were obtained through semi quantitative food frequency questionnaire. Blood pressure was measured with mercury sphygmomanometer. Rank Spearman correlation test was used on bivariate analysis.

Result: The prevalence of hypertension was 18,75\%. In food intake analysis, 57,81\% of subjects had sufficient total protein intake, 56,25\% of subjects had excessive plant protein and 92,19\% of subjects had excessive animal protein. In statistical analysis, there were significant correlation between total protein $(r-0,350 p=0,005 ; r-0,290 p=0,020)$ and animal protein $(r-0,557$ p 0,000; $r-0,559 p=0,000)$ with systolic and diastolic blood pressure. There were no significant correlation between plant protein intake with systolic blood pressure $(r-0,212 p=0,093)$.

Conclution: Total protein and animal protein correlate with systolic and diastolic blood pressure in adolescents.

Keywords : adolescents, blood pressure, total protein, plant and animal protein
\end{abstract}

\begin{abstract}
ABSTRAK
Latar belakang: Hipertensi tidak hanya terjadi pada dewasa, tetapi dapat terjadi pada remaja. Remaja yang mengalami hipertensi dapat terus berlanjut pada usia dewasa dan memiliki risiko mortalitas lebih tinggi. Berbagai faktor dapat mempengaruhi tekanan darah remaja, salah satunya asupan. Penelitian terbaru menunjukkan bahwa terdapat hubungan antara asupan protein dengan tekanan darah.

Tujuan: Penelitian ini bertujuan untuk mengetahui hubungan asupan protein dengan tekanan darah pada remaja. Metode: Penelitian cross sectional ini diikuti oleh 64 subjek remaja SMP Kesatrian 2 Semarang yang dipilih dengan metode simple random sampling. Asupan protein diperoleh melalui kuisioner semi quantitative food frequency. Data tekanan darah didapatkan dengan menggunakan sphygmomanometer air raksa. Analisis bivariat dilakukan dengan uji korelasi rank Spearman.

Hasil: Prevalensi hipertensi sebesar 18,75\%. Sebanyak 57,81\% subjek memiliki asupan protein total cukup, 56,25\% memiliki asupan protein nabati yang melebihi kebutuhan dan 92,19\% subjek memiliki asupan protein hewani yang melebihi kebutuhan. Terdapat hubungan yang signifikan antara asupan protein total $(r-0,350 p=0,005 ; r-0,290$ $p=0,020)$ dan protein hewani $(r-0,557 p=0,000 ; r-0,559 p=0,000)$ dengan tekanan darah sistolik dan diastolik. Tidak ada hubungan antara asupan protein nabati dengan tekanan darah sistolik ( $r$-0,212 p=0,093).
\end{abstract}

Simpulan: Asupan protein total dan hewani berhubungan dengan tekanan darah sistolik dan diastolik pada remaja. Kata kunci: remaja, tekanan darah, asupan protein total, protein nabati dan protein hewani

\section{PENDAHULUAN}

Hipertensi atau tekanan darah tinggi merupakan penyakit yang menjadi perhatian di banyak Negara di dunia. ${ }^{1}$ Berbagai komplikasi dapat terjadi pada penderita hipertensi seperti penyakit kardiovaskuler, stroke dan ginjal. $^{2}$ Adanya hipertensi pada masa anak berperan dalam perkembangan dini penyakit jantung koroner pada masa dewasa. ${ }^{2}$ Menurut survei yang dilakukan oleh World Health Organization (WHO) pada tahun 2000, jumlah penduduk dunia yang menderita hipertensi untuk wanita sekitar $24,1 \%$ dan pria sekitar 26,6\% serta diperkirakan pada tahun 2025 jumlahnya akan meningkat menjadi $29,21 \%{ }^{1}$

Hipertensi tidak hanya terjadi pada orang dewasa atau usia lanjut, tapi juga dapat terjadi pada remaja. ${ }^{2}$ Menurut Profil kesehatan jawa tengah tahun 2010, prevalensi hipertensi usia muda di kota Semarang sebanyak 164 kasus $(6,01 \%) .{ }^{3}$ Pada remaja hipertensi merupakan suatu masalah, karena remaja yang mengalami hipertensi dapat terus berlanjut pada usia dewasa dan memiliki risiko morbiditas dan mortalitas yang lebih tinggi. ${ }^{4}$ Walaupun prevalensi hipertensi secara klinis sedikit pada anak-anak dan remaja dibandingkan pada 
dewasa, namun cukup banyak bukti yang menyatakan bahwa hipertensi esensial pada orang dewasa dapat berawal dari masa anak-anak dan remaja. ${ }^{4}$

Berbagai faktor dapat memperbesar risiko kejadian hipertensi pada remaja diantaranya umur, jenis kelamin, genetik, obesitas, stress, aktifitas fisik, merokok, konsumsi alkohol dan asupan. ${ }^{1}$ Faktor asupan merupakan salah satu faktor yang dapat dikontrol. Berbagai asupan dianggap mempunyai peranan terhadap tekanan darah seperti asupan protein, lemak jenuh, natrium, kalium, kalsium, magnesium dan serat. ${ }^{5}$ Protein dibutuhkan dalam keadaan normal sekitar $0,95 \mathrm{gr} / \mathrm{kgBB} / \mathrm{hari}$ untuk usia 9-13 tahun dan $0,85 \mathrm{gr} / \mathrm{kgBB} / \mathrm{hari}$ untuk usia 14-18 tahun dengan proporsi protein nabati 60$80 \%$ dan protein hewani $20-40 \%$. ${ }^{6,7}$

Penelitian mengenai protein diantaranya, pada studi observasional INTERMAP telah membuktikan adanya hubungan negatif antara protein nabati dengan tekanan darah, sedangkan protein hewani berhubungan positif dengan tekanan darah. ${ }^{8}$ Penelitian terbaru Justin et al tahun 2014 pada subjek dewasa menunjukkan bahwa asupan protein total, nabati dan hewani berkorelasi negatif dengan tekanan darah sistolik dan diastolik. ${ }^{9}$ Penelitian kasus kontrol tahun 2012 pada subjek dewasa menunjukkan bahwa konsumsi tinggi protein selama 4 minggu mempunyai efek signifikan dengan penurunan tekanan darah sistolik 4,9 $\mathrm{mmHg}$ dan tekanan darah diastolik $2,7 \mathrm{mmHg}$ pada subjek overweight dengan prehipertensi dan hipertensi grade $1 .^{10}$ Penelitian sebelumnya tahun 2009 menunjukkan bahwa asupan protein total dan hewani berkorelasi negatif dengan tekanan darah, namun asupan protein nabati berkorelasi positif tidak bermakna dengan tekanan darah. ${ }^{11}$

Salah satu mekanisme penurunan tekanan darah adalah penghambatan ACE oleh bioaktif peptida. Hasil penghambatan ACE menurunkan pembentukan angiotensin II, mengurangi vasokonstriksi dan menurunkan resistensi perifer total serta menurunkan tekanan darah. ${ }^{12}$ Mekanisme lain dari hubungan asupan protein dengan tekanan darah adalah adanya asam-asam amino yang memiliki peran penting dalam regulasi pembuluh darah. ${ }^{11}$ L-arginin yang banyak terdapat pada protein hewani dan nabati merupakan substrat dari nitrit oksida (NO), nitrit oksida berfungsi sebagai vasodilator dan pengatur pertahanan vaskuler. Asam amino triptofan dan tirosin yang juga banyak terdapat pada protein hewani mempunyai efek antihipertensi karena adanya pembentukan serotonin pada sistem syaraf pusat. ${ }^{11}$
Berdasarkan latar belakang diatas peneliti tertarik untuk melihat hubungan asupan protein dengan tekanan darah pada remaja. Penelitian dilakukan di SMP Kesatrian 2 Semarang. Hasil penelitian Martalina tahun 2012 menunjukkan bahwa sekolah tersebut merupakan salah satu sekolah yang memiliki prevalensi hipertensi yang tinggi. ${ }^{13}$

\section{METODE}

Ruang lingkup penelitian adalah gizi masyarakat dengan desain cross sectional, yang dilaksanakan pada bulan Juni 2015. Data 64 responden diambil menggunakan teknik simple random sampling dengan populasi target adalah remaja awal usia 12-14 tahun di Kota Semarang, dan populasi terjangkau merupakan remaja awal usia 12-14 tahun di SMP Kesatrian 2 Semarang. Kriteria inklusi pengambilan data yaitu berumur 1214 tahun, tidak mengkonsumsi obat-obatan yang dapat mempengaruhi tekanan darah, tidak mengkonsumsi alkohol dan tidak merokok.

Variabel bebas dalam penelitian ini adalah asupan protein. Variabel terikat yaitu tekanan darah sistolik dan diastolik. Data yang dikumpulkan meliputi data umum subjek, data antropometri, data asupan, dan data tekanan darah. Data umum subjek diperoleh dari kuisioner penelitian. Data antropometri seperti berat badan responden diukur menggunakan timbangan digital dengan kapasitas $150 \mathrm{~kg}$ dan ketelitian $0,1 \mathrm{~kg}$, sedangkan tinggi badan diukur menggunakan microtoise dengan kapasitas $200 \mathrm{~cm}$ dan ketelitian 0,1 cm. Data asupan diperoleh melalui wawancara menggunakan Semi Quantitative Food Frequency Questionnary. Data tekanan darah subjek diukur lansung dengan menggunakan sphygmomanometer air raksa dengan oleh tenaga ahli kesehatan. Pemeriksaan tekanan darah dilakukan setelah pasien duduk tenang selama 5 menit tidak bergerak maupun berbicara, kaki menempel dilantai dan posisi lengan disangga setinggi jantung. Manset yang digunakan harus sesuai yang dapat melingkari sedikitnya $80 \%$ lengan atas. Ukuran cuff dan manset yang sesui untuk remaja yaitu panjang 18-24 cm dan lebar 10$12 \mathrm{~cm}^{14}$ Tekanan darah diambil 2 kali pada lengan kanan dan kiri dengan selang waktu 2 menit dan diambil rata-rata hasil keduanya. Apabila terjadi perbedaan lebih dari $10 \mathrm{mmHg}$ maka diulang untuk pemeriksaan yang ketiga yang dilakukan 15 menit kemudian. ${ }^{15}$ 
Pengelompokan hipertensi berdasarkan The Fourth Report On The Diagnosis, Evaluation, and Treatment of High Blood Pressure in Children and Adolescents yang menyatakan bahwa batasan hipertensi adalah nilai rata-rata tekanan darah sistolik dan atau diastolik lebih dari persentil ke95. ${ }^{16}$ Prehipertensi adalah nilai rata-rata tekanan darah sistolik dan atau diastolik antara persentil ke90 dan 95. Remaja dengan tekanan darah 120/80 $\mathrm{mmHg}$ harus dianggap prehipertensi. Tekanan darah remaja dikatakan normal apabila sistolik dan diastolik kurang dari persentil ke-90. ${ }^{16}$ Hasil pengukuran tekanan darah yang diperoleh kemudian dibandingkan dengan tabel tekanan darah anak laki-laki dan perempuan berdasarkan usia dan persentil tinggi badan.

Analisis univariat untuk mendiskripsikan data gambaran umum subjek meliputi distribusi frekuensi dan persentase. Data asupan protein dikategorikan menjadi kurang ( $<10 \%$ energi total), cukup (10-15\% energi total), lebih (>15\% energi total). ${ }^{17}$ Data asupan protein nabati dikategorikan menjadi kurang ( $<60 \%$ kebutuhan protein), cukup (60-80\% kebutuhan protein), lebih (>80\% kebutuhan protein). Data asupan protein hewani dikategorikan menjadi kurang $(<20 \%$ kebutuhan protein), cukup (20-40\% kebutuhan protein), lebih (>80\% kebutuhan protein). ${ }^{7}$ Uji kenormalan dengan menggunakan Kolmogorof-Smirnov, analisis bivariat menggunakan rank Spearman.

\section{HASIL PENELITIAN \\ Karakteristik Subjek Penelitian}

Karakteristik subjek berdasarkan usia, jenis kelamin, IMT (Indeks Masa Tubuh) dan tekanan darah dapat dilihat dalam tabel 1.

Tabel 1. Gambaran umum usia, IMT dan tekanan darah subjek berdasarkan jenis kelamin.

\begin{tabular}{lcccccc}
\hline \multirow{2}{*}{ Variabel } & \multicolumn{3}{c}{ Laki-laki $(\mathrm{n}=22)$} & \multicolumn{3}{c}{ Perempuan $(\mathrm{n}=27)$} \\
\cline { 2 - 7 } & Min & Max & Median & Min & Max & Median \\
\hline Usia (th) & 12 & 14 & 13,5 & 12 & 14 & 13 \\
IMT & 15.05 & 36,57 & 20,25 & 15,5 & 31,7 & 21,75 \\
$\begin{array}{l}\text { Tekanan darah } \\
\text { sistolik }\end{array}$ & 110 & 135 & 112,5 & 110 & 140 & 115 \\
$\begin{array}{l}\text { Tekanan darah } \\
\text { diastolik }\end{array}$ & 70 & 90 & 70 & 70 & 90 & 72,5 \\
\hline
\end{tabular}

Pengelompokan data usia, IMT, tekanan darah sistolik dan diastolik menggunakan median data, karena data berdistribusi tidak normal. Subjek pada penelitian berjumlah 64 orang yang terdiri dari 26 subjek laki-laki $(40,63 \%)$ dan 38 subjek perempuan $(59,37 \%)$. Usia subjek berkisar antara 12 - 14 tahun, sebagian besar subjek berusia 14 tahun $(50 \%)$. Tekanan darah sitolik berkisar antara 110-140 mmHg dan tekanan darah diastolik berada pada rentang $70-90 \mathrm{mmHg}$.

Tabel 2. Gambaran tekanan darah subjek berdasarkan jenis kelamin

\begin{tabular}{lccc}
\hline Jenis kelamin & \multicolumn{3}{c}{ Kategori Tekanan Darah } \\
\cline { 2 - 4 } & Normal n $(\%)$ & Prehipertensi n $(\%)$ & Hipertensi n $(\%)$ \\
\hline Laki -laki & 17 & 2 & 7 \\
Perempuan & 26 & 7 & 5 \\
Total & $43(69,75)$ & $9(14,06)$ & $12(18,75)$ \\
\hline
\end{tabular}

Sebanyak 12 subjek mengalami hipertensi $(18,75 \%)$ yang terdiri dari 7 orang laki-laki $(58,3 \%)$ dan 5 orang perempuan $(41,7 \%)$. Sebanyak 9 subjek $(14,06 \%)$ termasuk dalam kategori prehipertensi dan sisanya $43(69,75 \%)$ subjek termasuk dalam kategori normal.

\section{Gambaran Asupan Zat Gizi Subjek}

Sebanyak 37 subjek $(57,81 \%)$ memiliki asupan protein total yang sesuai dengan kebutuhan. Sebanyak 36 subjek $(56,25 \%)$ memiliki asupan protein nabati yang melebihi kebutuhan. Sebanyak 59 subjek $(92,19 \%)$ memiliki asupan protein hewani yang melebihi kebutuhan.
Tabel 3. Gambaran asupan makan subjek

\begin{tabular}{lcc}
\hline \multirow{2}{*}{ Asupan makan } & \multicolumn{2}{c}{ Subjek $(\mathrm{n}=64)$} \\
\cline { 2 - 3 } & $\mathrm{n}$ & $\%$ \\
\hline Protein Total & & \\
Kurang & 4 & 6,25 \\
Cukup & 37 & 57,81 \\
Lebih & 23 & 35,94 \\
Protein Nabati & & \\
Kurang & 16 & 25 \\
Cukup & 12 & 18,75 \\
Lebih & 36 & 56,25 \\
Protein Hewani & & \\
Kurang & 0 & 0 \\
Cukup & 5 & 7,81 \\
Lebih & 59 & 92,19 \\
\hline
\end{tabular}


Tabel 4. Gambaran asupan sumber protein hewani dan nabati pada subjek

\begin{tabular}{lccc}
\hline \multicolumn{1}{c}{ Asupan } & Min & Max & Median \\
\hline Sumber protein hewani & & & \\
Daging merah (g) & 0 & 26 & 25 \\
Unggas (g) & 18 & 110 & 37 \\
Ikan (g) & 10 & 74 & 17 \\
Telur (g) & 12 & 63 & 24 \\
Seafood (g) & 0 & 31 & 12 \\
Produk olahan daging (g) & 6 & 87 & 25,5 \\
Produk olahan susu (g) & 0 & 40 & 15 \\
\hline Sumber protein nabati & & & \\
Sayur (g) & 16 & 301 & 80 \\
Buah (g) & 20 & 394 & 121 \\
Kacang (g) & 0 & 57 & 10 \\
Produk kedelai (g) & 14 & 164 & 65 \\
\hline
\end{tabular}

Tabel 4 merupakan tabel asupan sumber protein hewani dan nabati pada subjek berdasarkan gram bahan makanan. Sebagian besar subjek penelitian mengasup sumber protein hewani seperti daging merah (daging sapi, kambing), unggas (daging ayam, bebek), hati ayam, hati sapi, telur ayam, produk olahan daging (sosis, bakso), ikan (ikan lele, bandeng, mangut, mujair, nila, kakap), seafood (udang, cumi, kerang, kepiting). Sumber protein hewani yang paling banyak dikonsumsi berasal dari unggas yaitu daging ayam. Bahan makanan sumber protein hewani yang paling sedikit dikonsumsi adalah udang. Satu satuan penukar lauk hewani mengandung $7 \mathrm{~g}$ protein.
Bahan makanan sumber protein nabati yang dikonsumsi subjek adalah tahu, tempe dan kacangkacangan. Satu satuan penukar dari tahu (110 g) tempe $\left(\begin{array}{ll}50 & \mathrm{~g}\end{array}\right)$ dan kacang-kacangan $\left(\begin{array}{ll}20 & \mathrm{~g}\end{array}\right)$ mengandung $5 \mathrm{~g}$ protein. Selain dari produk kedelai dan kacang-kacangan, serealia, umbi-umbian, sayur dan buah merupakan sumber protein nabati yang juga dikonsumsi subjek walaupun hanya mengandung protein yang sedikit. Satu satuan penukar dari serealia dan umbi-umbian mengandung $4 \mathrm{~g}$ protein. Satu penukar sayuran B $(100 \mathrm{~g})$ mengandung $1 \mathrm{~g}$ protein sedangkan sayuran $\mathrm{C}$ mengandung $3 \mathrm{~g}$ protein.

\section{Gambaran Asupan dan Tekanan Darah Subjek}

Tabel 5. Gambaran umum asupan protein total, hewani dan tekanan darah subjek

\begin{tabular}{|c|c|c|c|c|c|c|c|c|c|}
\hline \multirow{3}{*}{ Asupan } & \multicolumn{9}{|c|}{ Kategori Tekanan Darah } \\
\hline & \multicolumn{3}{|c|}{ Normal } & \multicolumn{3}{|c|}{ prehipertensi } & \multicolumn{3}{|c|}{ hipertensi } \\
\hline & Min & Max & Median & Min & $\max$ & median & Min & Max & Median \\
\hline $\begin{array}{l}\text { Protein } \\
\text { total }\end{array}$ & 41,7 & 127,5 & 73,8 & 52 & 63,5 & 56 & 47,7 & 93,1 & 64,4 \\
\hline $\begin{array}{l}\text { Protein } \\
\text { hewani }\end{array}$ & 18,6 & 87,8 & 40,7 & 19,3 & 40 & 20,7 & 12,6 & 54,2 & 18,5 \\
\hline
\end{tabular}

Tabel 6. Gambaran asupan protein nabati dan tekanan darah subjek

\begin{tabular}{cccc}
\hline \multirow{3}{*}{ Asupan } & \multicolumn{3}{c}{ Kategori Tekanan Darah } \\
\cline { 2 - 4 } & Normal & Prehipertensi & Hipertensi \\
\cline { 2 - 4 } & Mean \pm SD & Mean \pm SD & Mean \pm SD \\
\hline Protein nabati & $33,1 \pm 10,16$ & $34,8 \pm 9,39$ & $39,1 \pm 14,28$ \\
\hline
\end{tabular}

Pengelompokan asupan protein total dan protein hewani berdasarkan median data, karena data berdistribusi tidak normal. Median asupan protein total pada subjek dengan tekanan darah normal lebih besar $(73,8 \mathrm{~g})$ dibandingkan dengan subjek yang memiliki tekanan darah hipertensi $(64,4 \mathrm{~g})$ dan prehipertensi $(63,5 \mathrm{~g})$, sedangkan median asupan protein hewani semakin menurun dari subjek yang memiliki tekanan darah normal hingga tinggi. Berbeda asupan protein nabati, pengelompokan data menggunakan mean data karena data berdistribusi normal. Rerata asupan protein nabati semakin meningkat dari subjek yang memiliki tekanan darah normal hingga tinggi.

Hubungan Asupan dan Tekanan Darah Subjek 
Tabel 7. Hubungan asupan protein total, nabati, hewani, natrium, kalium dan kalsium dengan tekanan darah sistolik dan diastolik subjek

\begin{tabular}{lcccc}
\hline \multirow{2}{*}{ Variabel } & \multicolumn{2}{c}{ Tekanan darah sistolik } & \multicolumn{2}{c}{ Tekanan darah diastolik } \\
\cline { 2 - 5 } & $\mathrm{r}$ & $\mathrm{p}$ & $\mathrm{r}$ & $\mathrm{p}$ \\
\hline Asupan protein total & $-0,350$ & 0,005 & $-0,290$ & 0,020 \\
Asupan protein nabati & 0,230 & 0,068 & 0,292 & 0,019 \\
asupan protein hewani & $-0,557$ & 0,000 & $-0,559$ & 0,000 \\
\hline
\end{tabular}

Analisis korelasi asupan protein total dengan tekanan darah yang ditunjukkan pada tabel 7, didapatkan hasil bahwa terdapat korelasi negatif dengan kekuatan korelasi yang lemah antara asupan protein total dengan tekanan darah. Hal ini berarti semakin tinggi asupan protein total maka tekanan darah sistolik $(r=-0,350 ; p=0,005)$ dan diastolik $(r=-0,290 ; p=0,020)$ akan semakin rendah. Pada analisis korelasi asupan protein nabati dengan tekanan darah sistolik menunjukkan tidak ada hubungan signifikan $(r=0,230 ; p=0,068)$. Namun, pada analisis hubungan asupan protein nabati dengan tekanan darah diastolik $(r=0,292 ; p=0,019)$ menunjukkan adanya hubungan yang signifikan. Hasil analisis korelasi menunjukkan bahwa terdapat hubungan signifikan dengan arah korelasi negatif antara asupan protein hewani dengan tekanan darah sistolik $(r=-0,557 ; p=0,000)$ dan diastolik $(r=$ $0,559 ; p=0,000)$.

\section{PEMBAHASAN}

Dalam penelitian, terdapat 12 subjek $(18,75 \%)$ yang mengalami hipertensi. Sebanyak 9 subjek $(14,06 \%)$ termasuk dalam kategori prehipertensi dan sisanya 43 subjek $(69,75 \%)$ memiliki tekanan darah yang normal. Angka kejadian hipertensi tersebut jika dibandingkan dengan Profil Kesehatan Jawa Tengah tahun 2010 termasuk tinggi karena di kota Semarang prevalensi hipertensi pada usia muda tahun 2009 terjadi sebanyak 164 kasus $(6,01 \%)$. Namun, apabila dibandingkan dengan penelitian Martalina tahun 2012 hipertensi pada penelitian ini lebih rendah karena pada penelitian Martalina didapatkan prevalensi hipertensi 30,03\%.

Kejadian hipertensi lebih banyak ditemukan pada remaja laki-laki dibandingkan perempuan karena dari 12 subjek $(18,75 \%)$ yang mengalami hipertensi, 7 orang (10,93\%) diantaranya adalah laki-laki dan sisanya 5 perempuan $(7,82 \%)$. Pada remaja, tekanan darah laki-laki biasanya lebih tinggi daripada perempuan selama dekade pertama kehidupan. Perbedaan tekanan darah mulai meluas selama masa pubertas dan tekanan darah remaja laki-laki secara signifikan lebih tinggi pada akhir masa remaja. ${ }^{4}$ Perbedaan sekresi hormon godonal selama masa pubertas inilah yang mempengaruhi perbedaan tekanan darah pada remaja. ${ }^{18}$

Analisis bivariat menunjukkan bahwa asupan protein total berkorelasi negatif secara signifikan dengan tekanan darah sistolik dan diastolik. Protein hewani juga berkorelasi negatif secara signifikan dengan tekanan darah sistolik dan diastolik. Hubungan yang negatif berarti bahwa semakin tinggi asupan protein total dan protein hewani maka tekanan darah akan semakin rendah. Hasil penelitian ini sesuai dengan penelitian lain yang menunjukkan bahwa adanya hubungan negatif antara peningkatan asupan protein total dan protein hewani dengan penurunan tekanan darah. ${ }^{11}$

Mekanisme penurunan tekanan darah oleh protein disebakan oleh biopeptida dan asam-asam amino dalam protein. Hasil penghambatan ACE oleh bioaktif peptida menurunkan pembentukan angiotensin II,mengurangi vasokonstriksi dan menurunkan resistensi perifer total serta menurunkan tekanan darah. ${ }^{12}$ Selain itu, asam-asam amino memiliki peran yang penting dalam regulasi pembuluh darah. ${ }^{11}$ Asam amino arginin, yang banyak terdapat pada sumber protein hewani seperti daging sapi, daging ayam, telur, sosis, jerohan, dan ikan yang meliputi ikan air tawar, asin dan tambak, bertindak sebagai substrat dari nitrit oxide (NO). ${ }^{11,19}$ Arginin dapat meningkatkan bioavaibilitas nitrit oxide (NO), yang bertindak sebagai vasodilator dan pengatur pertahanan vaskuler. ${ }^{11}$ Selain itu, mekanisme potensial L-arginin pada hipertensi adalah (1) meningkatkan fungsi vasomotor endothelial (2) meningkatkan sintesis nitrit oksida vaskuler (3) menurunkan aktivitas endotelin I dan angiotensin II (4) meningkatkan sensitifitas insulin. ${ }^{20}$ Regulasi arginin dalam meningkatan sensitifitas insulin dari sel beta di pankreas dapat menekan pembentukan angiotensinogen oleh angiotensin II sehingga tidak terjadi vasokontriksi. ${ }^{21}$

Asam amino lain seperti triptofan dan tirosin yang banyak terdapat pada protein hewani mempunyai efek antihipertensi karena adanya pembentukan serotonin pada sistem syaraf pusat. ${ }^{9}$ Asam amino triptofan mampu mempengaruhi neurotransmitter atau substansi humoral yang dapat mengontrol tekanan darah. ${ }^{22}$ Serotonin merupakan neurotransmitter monoaminergik yang mempengaruhi vasokonstriksi, motilitas usus, 
hemostasis primer, perbaikan hati, dan kontrol sel T. ${ }^{23}$ Peningkatan kadar serotonin plasma dan peningkatan pergantian serotonin dapat menurunkan tekanan darah. ${ }^{23}$

Hasil analisis menunjukkan tidak adanya hubungan antara asupan protein nabati dengan tekanan darah sistolik. Namun, pada analisis hubungan asupan protein nabati dengan tekanan darah diastolik terdapat hubungan signifikan dengan arah korelasi positif yang lemah. Peneltian sebelumnya juga menunjukkan bahwa asupan protein nabati berkorelasi positif tidak bermakna dengan tekanan darah, tetapi hubungan yang tidak bermakna tersebut masih belum diketahui sebabnya. ${ }^{11}$ Hasil penelitian ini berkebalikan dengan studi observasional INTERMAP yang menunjukkan bahwa asupan protein nabati berkorelasi negatif dengan tekanan darah. ${ }^{8}$

Sebagian besar makanan sumber protein nabati merupakan incomplete proteins. ${ }^{25}$ Incomplete proteins memiliki biological value yang rendah dan biasanya tidak menyediakan semua asam amino esensial atau menyediakan beberapa dari asam amino namun dalam jumlah yang terbatas. $^{25,26}$ Selain itu, sumber protein nabati mengandung asam amino glutamat, sistin, prolin, fenilalanin dan serin yang lebih tinggi dibandingkan dengan sumber protein hewani. ${ }^{8}$ Sebaliknya, sumber protein hewani cenderung mengandung arginin, tirosin, leusin yang lebih tinggi dibanding protein nabati. ${ }^{8,24,27}$ Ketidaksesuaian dalam penelitian ini mungkin disebabkan sedikitnya kandungan asam amino arginin, tirosin, leusin pada protein nabati karena protein nabati hanya menyediakan sumber asam amino yang terbatas. Berbagai faktor asupan lain berhubungan dengan tekanan darah, seperti asupan serat, natrium, kalium, kalsium dan magnesium. ${ }^{28}$ Asupan tersebut kemungkinan juga berpengaruh terhadap tekanan darah subjek.

\section{SIMPULAN}

Terdapat hubungan signifikan antara asupan protein total dan protein hewani dengan tekanan darah sistolik dan diastolik.

\section{SARAN}

Pemilihan sumber protein yang tepat dengan proporsi yang sesuai kebutuhan dapat memberikan efek pada tekanan darah.

\section{DAFTAR PUSTAKA}

1. Febby Haendra Dwi Anggara dan Nanang Prayitno. Faktor-Faktor Yang Berhubungan dengan Tekanan Darah di Puskesmas Telaga Murni, Cikarang Barat Tahun 2012. Jurnal Ilmiah Kesehatan 2013.
2. Made Supartha, I Ketut Suarta, dan Ida Bagus Agung Winaya. Hipertensi pada Anak. Maj Kedokt Indon 2009.

3. Dinas Kesehatan Provinsi Jawa Tengah. Buku Profil Kesehatan Provinsi Jawa Tengah Tahun 2010.

4. Johanes HS. Hipertensi pada Remaja. Sari Pediatri 2005: 159-165

5. Apriany, Rista Emiria Afrida. Asupan Protein, Lemak Jenuh, Natrium, Serat dan IMT terkait dengan Tekanan Darah Pasien Hipertensi di RSUD Tugurejo Semarang. Skripsi. Semarang: Fakultas Kedokteran Universitas Diponegoro. 2012

6. Mahan LK, Stump SE, Raymond JL, editors. Krauses's Food \& The Nutrition Care Process. 13th ed. USA-Elsevier Saunders; 2012. p : 415-466; 1080.

7. Ahmad Djaelani Sediaoetama. Ilmu Gizi untuk Mahasiswa dan Profesi. Jakarta: Dian Rakyat; 2000.p:34.

8. Elliott P, Stamler J, Dyer AR, Appel L, Dennis B, Kesteloot $\mathrm{H}$, et al. Association between protein intake and blood pressure: the INTERMAP Study. Arch Intern Med 2006;166: 79-87

9. Justin R. Buendia, M. Loring Bradlee, Martha R. Singer, and Lynn L. Moore. Diets Higher in Protein Predict Lower High Blood Pressure Risk in Framingham Offspring Study Adults. American Journal of Hypertension. 2014.

10. FM Teunissen-Beekman, Janneke Dopheide, Johanna M Geleijnse, Stephan JL Bakker, Elizabeth J Brink, Peter W de Leeuw, et al. Protein supplementation lowers blood pressure in overweightadults: effect of dietary proteins on blood pressure (PROPRES), a randomized trial1-3. Am J Clin Nutr 2012;95:966-71

11. Mitsumasa Umesawa, Shinichi Sato, Hironori Imano, Akihiko Kitamura, Takashi Shimamoto, Kazumasa Yamagishi, et al. Relations between protein intake and blood pressure in Japanesemen and women: the Circulatory Risk in CommunitiesStudy (CIRCS)1-3. Am J Clin Nutr 2009;90:377.

12. Teunissen-Beekman, Karianna F.M. van Baak, and Marleen A. The role of dietary protein in blood pressure regulation. Curr Opin Lipidol. 2013;24:6570.

13. Martalina, Tri Kapriana. Asupan Tinggi Lemak dan Aktifitas Fisik sebagai Faktor Resiko terjadinya Hipertensi Obesitas pada Remaja Awal. Skripsi. Semarang: Fakultas Kedokteran Universitas Diponegoro. 2012

14. British Hypertension Society. Blood Pressure Measurentment With Manual Blood Pressure Monitors. [serial online] [cited 2015 Jun 23]. Available from URL:http://www.bhsoc.org/files/9013/4390/7747/ BP_Measurement_Poster_-_Manual.pdf 
15. Mexitalia, M., dkk. Sindroma Metabolik pada Remaja Obesitas. M Med IndonesVolume 43, Nomor 6, Tahun 2009.

16. National Institutes of Health National Heart, Lung, and Blood Institute. The Fourth Report On The: Diagnosis, Evaluation, and Treatment of High Blood Pressure in Children and Adolescents. NIH Publication 2005:05-5267.

17. Rolfes SR, Pinna K, Whitney E. Understanding Normal and Clinical Nutrition. 8th ed. Page I-1

18. Shankar RR, Eckert GJ, Saha C, Tu W and Pratt JH. The change in blood pressure during pubertal growth. J Clin Endocrinol Metab. 2005;90(1):1637

19. Ainun AR. Hubungan Asupan Monosakarida, Pufa, Arginin, Asam Glutamate, dan Massa Lemak Tubuh dengan Tekanan Darah pada Wanita Post Menopause. Skripsi. Semarang: Fakultas Kedokteran Universitas Diponegoro. 2013.

20. Gocke, Noyan. L-arginine and hypertension. American Society for Nutritional Science. 2004 0022-3166/04.

21. Vasdev S, Gill V. Antihypertensive Effect of Arginine. Int J Angiol 2008:17 (1):7-22

22. Kotchen TA, Kotchen JM. Nutrition, Diet, and Hypertension. In: Shils ME. Modern Nutrition in Health and Disease $10^{\text {th }}$ edition. Philadelpia: Lippincott Williams and Wilkins; 2006.p.10951102

23. Ardiansyah, Hitoshi Shirakawa, Yuto Inagawa, Takuya Koseki and Michio Komai. Regulation of blood pressure and glucose metabolism induced by L-tryptophan in stroke-prone spontaneously hypertensive rats. Nutrition \& Metabolism 2011, 8:45

24. Steen, Celine and Tamasin Noyes. The Great Vegan Protein. Fair Wind Press; 2015.p7-8.

25. Stanfield, Peggy and YH Hui. Nutrition and Diet Therapy Self-Instructional Approaches Fifth Edition. Library of Congress Cataloging; 2009.p3637.

26. Jeremiah Stamler, et al. Glutamic Acid, the Main Dietary Amino Acid and blood Pressure. The INTERMAP study. Journal of American Heart Association. 2009. (120). p. 211-8.

27. J. Appel, Michael W. Brands, Stephen R. Daniels, Njeri Karanja, Patricia J. Elmer, Frank M. Sacks. Dietary Approaches to prevent and treat hypertension: A Scientific Statement From the American Heart association. Hyper J AHA 2006;47:296-308. 